\title{
Imaging of brain glucose uptake by PET in obesity and cognitive dysfunction: life-course perspective
}

\author{
Patricia lozzo and Maria Angela Guzzardi \\ Institute of Clinical Physiology, National Research Council (CNR), Pisa, Italy
}

Correspondence should be addressed to P lozzo: patricia.iozzo@ifc.cnr.it

\begin{abstract}
The prevalence of obesity has reached epidemic proportions and keeps growing. Obesity seems implicated in the pathogenesis of cognitive dysfunction, Alzheimer's disease and dementia, and vice versa. Growing scientific efforts are being devoted to the identification of central mechanisms underlying the frequent association between obesity and cognitive dysfunction. Glucose brain handling undergoes dynamic changes during the life-course, suggesting that its alterations might precede and contribute to degenerative changes or signaling abnormalities. Imaging of the glucose analog ${ }^{18} \mathrm{~F}$-labeled fluorodeoxyglucose $\left({ }^{18} \mathrm{FDG}\right)$ by positron emission tomography (PET) is the gold-standard for the assessment of cerebral glucose metabolism in vivo. This review summarizes the current literature addressing brain glucose uptake measured by PET imaging, and the effect of insulin on brain metabolism, trying to embrace a life-course vision in the identification of patterns that may explain (and contribute to) the frequent association between obesity and cognitive dysfunction. The current evidence supports that brain hypermetabolism and brain insulin resistance occur in selected high-risk conditions as a transient phenomenon, eventually evolving toward normal or low values during life or disease progression.

Associative studies suggest that brain hypermetabolism predicts low BDNF levels, hepatic and whole body insulin resistance, food desire and an unfavorable balance between anticipated reward from food and cognitive inhibitory control. Emerging mechanistic links involve the microbiota and the metabolome, which correlate with brain metabolism and cognition, deserving attention as potential future prevention targets.
\end{abstract}

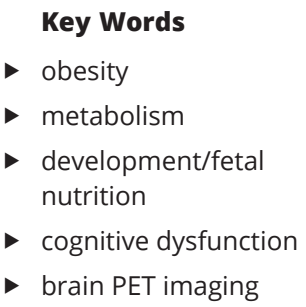

Endocrine Connections (2019) 8, R169-R183

\section{Introduction}

The prevalence of obesity has reached epidemic proportions and is growing in most world regions. Obesity is a risk factor for a series of chronic morbidities, the most frequent being type 2 diabetes. According to the World Health Organization (WHO), overweight and obesity have been estimated to account for about $65-80 \%$ of new cases of type 2 diabetes (http://www.euro.who .int/en/health-topics/noncommunicable-diseases/dia betes/data-and-statistics). Obesity and type 2 diabetes have been implicated in the pathogenesis of cognitive dysfunction (1). A number of studies have documented that people with obesity (especially in middle-age) and/or type 2 diabetes have a greater risk to develop dementia and Alzheimer's disease $(2,3,4,5)$. Clustering of these morbidities is fostered by population aging, whose rate of progression seems especially marked in Europe, North America and China, with 30\% or more people reaching $\geq 60$ years of age in 2050 (https://www.who.int /ageing/events/world-report-2015-launch/en/). Notably, the prevalence of overweight and obesity is enriched in

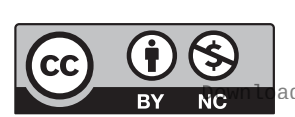

This work is licensed under a Creative Commons Attribution-NonCommercial 4.0 International License. ded from Bioscientifica.com at 04/26/2023 12:37:54PM 
these same countries. Nearly $60 \%$ of Europeans and North Americans are affected, and China hosts 20\% of the world overweight population (http://www.euro.who.int/en/ health-topics/noncommunicable-diseases/obesity/dataand-statistics). These concepts are summarized in Fig. 1.

The risk of obesity is settled, at least in part, during the earliest phases of life, as the brain undergoes its major development, involving a five-fold volumetric spurt in the first 5 years of life (6). Several early-life factors may affect the propensity of infants to become obese children, adolescents, and adults. These include maternal exposures (obesity, diabetes, stress) $(7,8,9)$, mode of delivery (e.g. C-section) (10), early nutrition (11, 12, 13, $14,15)$. Interestingly, these early risk factors have been also associated with a greater risk of premature cognitive decline, from early life to elderly age $(16,17,18,19,20)$.

Growing scientific efforts are being devoted to the identification of central mechanisms underlying the mutual reinforcement exerted by obesity on cognitive dysfunction and vice versa. Both have been associated with morphological reductions in brain volume, relating to systemic dysmetabolism and insulin resistance and/or to the degree of cognitive impairment $(21,22$, 23). Glucose is the most important brain fuel and central signaling factor. Glucose brain handling undergoes dynamic changes during the life-course, suggesting that its alterations might precede and contribute to degenerative changes or signaling abnormalities $(24,25)$. Imaging of the glucose analog ${ }^{18} \mathrm{~F}$-labeled fluorodeoxyglucose $\left({ }^{18} \mathrm{FDG}\right)$ by positron emission tomography (PET) is the gold standard for the assessment of cerebral glucose metabolism in vivo. In this manuscript, we review evidence on brain glucose uptake measured by PET imaging, trying to embrace a life-course vision in the identification of patterns that may explain (and contribute to) the frequent association between obesity and cognitive dysfunction.

\section{Brain glucose metabolism and PET imaging}

The brain relies primarily on glucose as its main energy source. Given its elevated utilization of circulating glucose, the brain may contribute to regulate peripheral glucose levels in a direct manner, by subtracting glucose from blood. Beyond nourishing the tissue, glucose is a signaling factor, informing central regulatory circuits on the metabolic and feeding conditions of the body (26, $27)$. In the brain, glucose stimulates the production of

\section{A Prevalence of overweight}

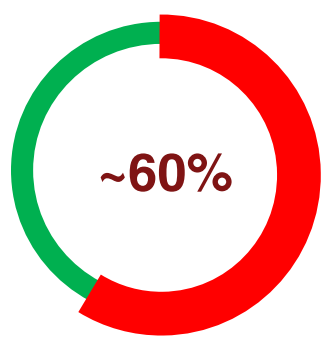

\section{Age 60 years or older by 2050}
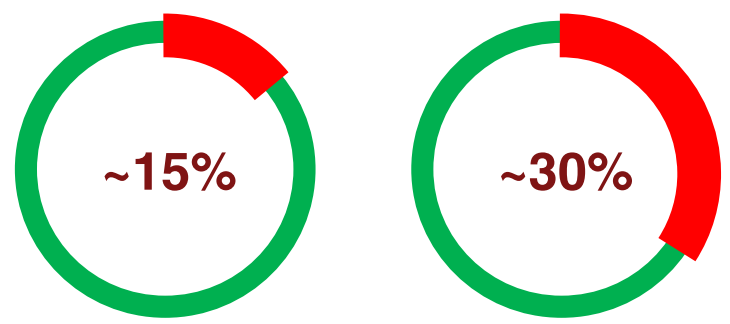

B

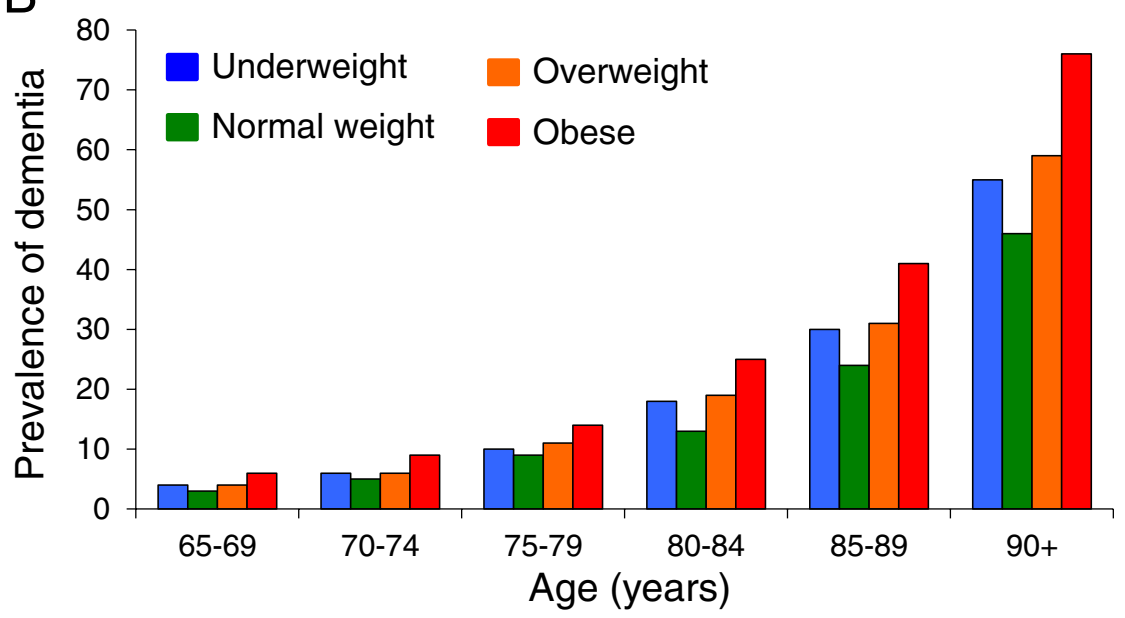

Figure 1

The three circles in panel A show the current prevalence of overweight (left) or dementia (middle) in Europe, and (on the right) the estimated aging of the European population in 2050, further promoting these conditions. Panel B (from data presented by Laurie Brown at the National Dementia Congress, Melbourne 2014 and (115)) depicts the prevalence of dementia by $\mathrm{BMI}$ status, across age categories.

(c) 2019 The authors Published by Bioscientifica Ltd

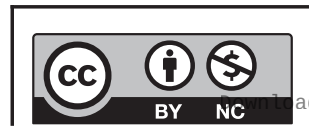

This work is licensed under a Creative Commons Attribution-NonCommercial 4.0 International License. ded from Bioscientifica.com at 04/26/2023 12:37:54PM 
rewarding neurotransmitters $(28,29,30,31)$, thereby contributing to appetite control and more in general to mental well-being. Brain sensing translates in the regulation of metabolically relevant organs and processes, including insulin secretion by pancreatic beta-cells (32, $33,34,35)$, hepatic glucose production $(36,37,38,39)$ and fatty acid release by adipose tissue lipolysis $(40,41)$. This partly occurs via afferent and efferent nerves. In turn, insulin can cross the blood-brain barrier to tune central control (42), and fatty acids can reach the brain (43), representing its main structural constituent (44). The characterization of brain glucose uptake in groups of individuals of progressive ages has shown important changes occurring throughout the lifespan. Supporting the five-fold expansion in gray matter observed in the first 5 years of life (6), brain glucose uptake undergoes a $>$ fourfold increase from birth to pre-scholar and early-scholar periods (24). This is followed by a relatively rapid decline, already from the age of 7-8 years and throughout the teenage period, reducing brain glucose uptake by $20-30 \%$ of its maximum, as opposed to only $10 \%$ gray matter losses. A brain volume reduction of $30 \%$ is achieved in late adulthood, a time in which glucose uptake has fallen by $60 \%$ from its maximum $(24,25)$. These time trends suggest that functional, namely metabolic changes are larger and detectable in advance of their morphological counterpart. It is therefore not surprising that FDG-PET imaging provides the earliest biomarker predicting neurodegenerative disease, as compared to other imaging (amyloid PET, magnetic resonance) or clinical modalities (signs and symptoms, cerebrospinal fluid markers) (45).

Compared to alternative methods to assess brain glucose metabolism in vivo, including arterial-venous catheterization or micro-dialysis, PET imaging is minimally invasive, and provides regional information, best reflecting the functional diversification between highly specialized brain areas. Once injected in a study subject, ${ }^{18} \mathrm{FDG}$ undergoes extraction by the brain and body tissues in proportion to their requirements. Graphical (46) and compartmental models (47) have been widely used to translate tissue and blood concentrations into biologically meaningful rate constant values, describing the transfer of ${ }^{18} \mathrm{FDG}$ from blood to brain cells and its subsequent phosphorylation. The fractional tissue extraction rate constant describes the relative amount (or percentage) of ${ }^{18} \mathrm{FDG}$ that is extracted from the circulation in a unit of time and tissue volume (or mass). In order to convert this factor into an absolute rate of glucose uptake, one has to account for the organ-specific lumped constant and the level of circulating glucose (48). The former corrects for different affinities of transporters and enzymes (hexokinases) for glucose compared to ${ }^{18} \mathrm{FDG}$, whereas the latter translates fractional (\%) into absolute rates of glucose influx into the target tissue (e.g. $\mu \mathrm{mol} / \mathrm{min} / \mathrm{g}$ ). Hence, the actual amount of glucose entering the tissue is given by the product of fractional extraction rate constant of ${ }^{18} \mathrm{FDG}$ and plasma glucose level, divided by the lumped constant term. Though the term glucose uptake may have been used interchangeably in the literature to define either absolute (glucose) or relative $\left({ }^{18} \mathrm{FDG}\right)$ tissue influxes, there is an important conceptual and numerical difference between these two processes. In neurodegenerative diseases, the extraction is frequently reported, with fewer studies quantifying absolute brain glucose uptake rates. The opposite is true in obesity studies. In this review, we primarily refer to the absolute value.

\section{Homeostatic regulation of brain glucose metabolism in obesity}

In humans, brain glucose metabolism has been studied in the fasting state or during euglycemic insulin stimulation. In adults, data from PET imaging studies indicate that the brain accounts for at least 50\% of whole-body glucose disposal during the fasting state and 10-20\% during euglycemic insulin stimulation, supporting an important direct role of this organ in affecting glycemia $(42,49,50,51,52)$. Studies have compared obese and lean individuals, as well as patients with glucose intolerance and normo-tolerant BMI-matched controls $(42,52)$. The evidence from these studies indicates that fasting insulin levels may serve to maintain a physiological tone of brain glucose uptake, since the inhibition of insulin secretion suppresses glucose uptake values in healthy individuals (49), whereas the elevation of insulinemia toward postprandial levels does not further affect cerebral glucose uptake compared to fasting values in non-obese healthy subjects $(50,51,52)$.

Compared to lean, obese subjects showed higher fasting metabolism in the parietal somatosensory cortex regions where sensation of the mouth, lips and tongue are located (53), and in regions regulating executive function (54). Other studies could not find differences between fasted lean and obese individuals, but observed elevated uptake of glucose in most brain regions during insulin stimulation in glucose-intolerant or morbidly obese patients $(42,52)$. In the latter, the elevation in brain glucose uptake was associated with greater endogenous

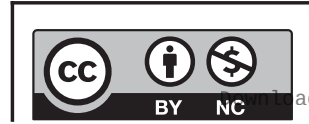

This work is licensed under a Creative Commons Attribution-NonCommercial 4.0 International License. ded from Bioscientifica.com at 04/26/2023 12:37:54PM 
glucose release (indicative of hepatic insulin resistance), and lower peripheral glucose consumption (primarily reflecting skeletal muscle insulin resistance), suggesting that brain hypermetabolism is the expression of central insulin resistance (55). In the same study, high brain glucose uptake was also shown to negatively predict the improvement in glucose levels occurring after weight loss in morbidly obese patients, thus contrasting one of the most relevant clinical benefits of bariatric surgery, that is, the recovery from type 2 diabetes. Consistent with the above evidence, the injection of glucose in cerebral ventricles caused a suppression of hepatic glucose production in healthy mice (38), but a 4-week infusion failed to provoke any effect in type 2 diabetic rats (56). Controlled studies in pigs replicate the human findings, by showing no brain glucometabolic response to euglycemic hyperinsulinemia (compared to fasting state) in control pigs, as opposed to an elevated response in pigs fed a high-fat diet (57). Studies in Zucker fatty or diabetic rats have shown that their brain glucose uptake is chronically elevated under fasting and glucose loading conditions, lacking the excursion that normally signals the transition from a fasted to fed state (58). We also reported that young pre-obese Zucker fatty rats, showing normal body weight but impaired glucose tolerance, already manifest brain hypermetabolism during a glucose tolerance test (59). Overall, the available evidence in human and animal studies, as exemplified in Fig. 2, suggests that a chronic overexposure of the brain to glucose may interrupt relevant feedback loops.

\section{Hedonic regulation of brain glucose metabolism in obesity}

Glucose can stimulate the production of rewardpromoting neurotransmitters in the brain $(29,30,31$, 60,61 ). Few studies have used FDG PET imaging to address the involvement of brain glucose uptake in the hedonic regulation of appetite and body weight, which is an important underlying element in the pathogenesis of obesity. One early study suggested that an enhanced metabolic activity in regions involved with sensory processing of food in obese subjects could make them more sensitive to the rewarding properties of preferred foods, contributing to excessive food consumption (53). Upon sensory (visual, taste, olfactory) stimulation with palatable food, all brain regions experience a rise in glucose uptake, compared to neutral sensing (62). Gender differences were noted in this response, since women showed greater metabolic activation than men
A

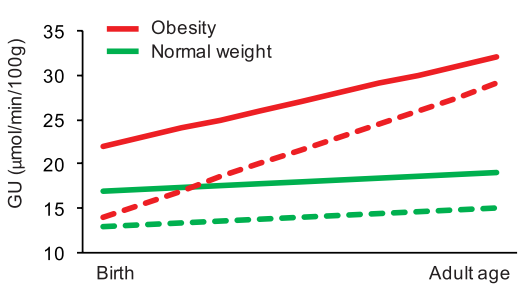

B

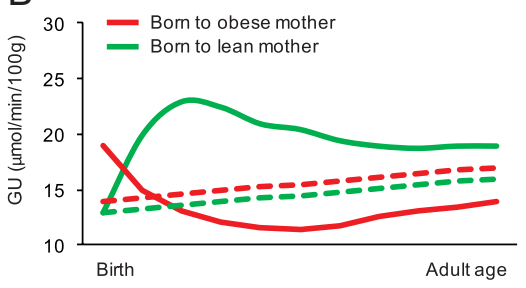

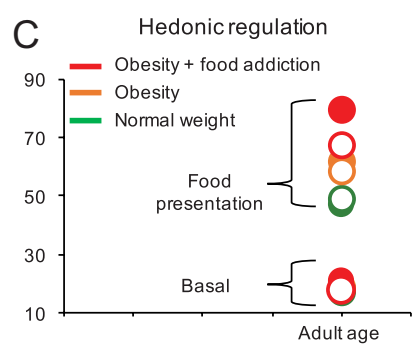

D Obesity and neurodegenerative disease

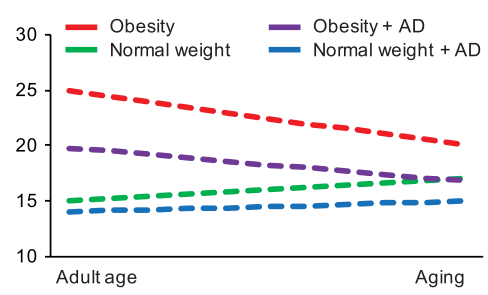

$\mathrm{E}$

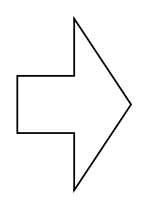

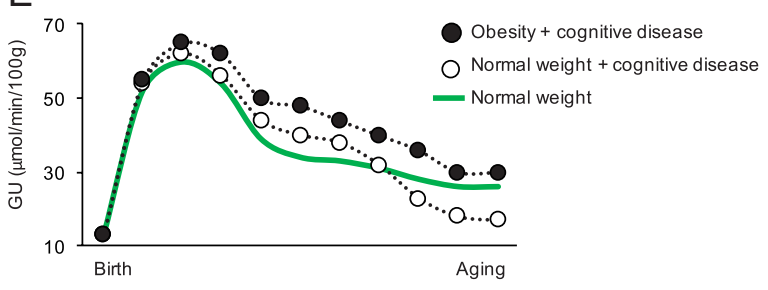

\section{Figure 2}

The figure summarizes the patterns of brain glucose metabolism described in this review. Panel A shows that the development of obesity in a genetic rodent model (Zucker rat) is characterized by brain hypermetabolism both in fasting condition (dashed lines) and during oral glucose tolerance test (solid line) (59). Panel B illustrates the effect of exposure to maternal obesity, resulting in a hypermetabolic brain response to isoglycemic insulin stimulation (solid line) in very early life (70), and mild brain hypermetabolism in fasting conditions (dashed lines) (92). Panel C shows the progressive increase of brain glucose uptake in response to food presentation in inhibitory control regions (open circles) and in reward related regions (closed circles) from normal weight women to women with obesity without and with food addiction $(62,64)$ in adult age. In panel $D$, a progressive increment in fasting brain glucose uptake from normal weight mice with Alzheimer's disease ( $A D$, blue line), to normal weight mice without $A D$ (green line), obese mice with $A D$ (purple line) and obese mice without AD (red line) is shown (69). Based on the above observations, panel E provides a simulation of how cognitive disease, with or without obesity, may modify (black lines) the physiological time-course (green line, (24) of brain metabolism over life.

https://ec.bioscientifica.com

https://doi.org/10.1530/EC-19-0348 (c) 2019 The authors Published by Bioscientifica Ltd

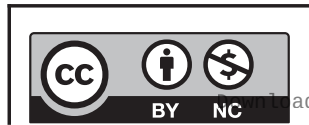

This work is licensed under a Creative Commons Attribution-NonCommercial 4.0 International License. ded from Bioscientifica.com at 04/26/2023 12:37:54PM 
in several brain regions, and minimal response to an inhibitory control cognitive task against their preferred food stimulation, as opposed to men in whom the cognitive task diffusely suppressed brain metabolism (right insula, right striatum, amygdala, hypothalamus, anterior cingulate, hippocampus, parahippocampal gyrus, orbitofrontal cortex, cerebellum) and hunger ratings (63). Unfortunately, the study did not involve obese patients. We have recently hypothesized that the magnitude and regional distribution of hedonic food responses might differ between similarly obese individuals, opening the opportunity for mechanistic based stratification, and personalized management of obese patients. In order to prove this concept, we studied two groups of obese women, who had similar metabolic profile and BMI, but different severity of food addiction symptoms, as based on the DMS Yale Food Addiction Scale (64). Compared to women with few symptoms, the more severely affected group showed greater brain metabolic activation in response to palatable versus neutral food cues, especially in rewardrelated regions, and less in inhibitory control regions (64). A lower response in inhibitory regions was predictive of a greater number of symptoms and hunger, which recalls the negative association described by others between BMI and prefrontal metabolism (65). Brain glucose responses and hunger ratings were reduced after modest dietinduced weight loss in the group with a food addicted profile, whereas no change was observed in control women (64). These proof-of-principle results strengthen the evidence of different obesity types, showing distinct metabolic brain reactions to food cues and to inhibitory control. Notably, the observation that the normalization of brain (hyper)metabolism during food sensing occurred together with a decreased perception of hunger was common to the acute cognitive inhibitory task in men (63) or the more prolonged diet-control effort in women (64). Animal studies exploring brain glucose uptake during hedonic (olfactory) stimulation with palatable food (bacon) show that caloric restriction, food desire and (Zucker) genotype influence central glucose metabolic responses via a complex interplay, especially in the hippocampus (a brain region that is increasingly involved in food behaviors) and superior colliculus (a brain region that modulates the saliency value of food reinforcers) (66). Figure 2 exemplifies the above observations, collectively suggesting that (a) brain metabolism relates to perceived hunger but does not respond similarly to palatable foods and food restriction in all individuals; (b) gender, obesity, ability to cognitively control, food addiction symptoms (shown in humans), and obesity-prone genotype versus food accessibility (reported in rodents) contribute to differentiate brain glucose responses; (c) more studies are definitely needed to understand to what extent the amount of glucose entering brain regions involved in homeostatic, hedonic, and cognitive control can modulate feeding behavior; (d) better understanding and account of the above interactions is likely to lead to tailored weight control interventions.

\section{Brain metabolism as common feature in obesity and neurodegenerative disease}

In the context of obesity research, the literature summarized above indicates that high cerebral metabolic rates occur in obese and glucose-intolerant subjects during fasted or homeostatic stimuli (i.e. hyperinsulinemia during eu- or hyperglycemia). Brain glucose uptake is normally increased in response to hedonic stimuli in lean individuals, especially in regions related with food sensing and reward (62). This effect is particularly pronounced in obese food addicted women in the whole brain $(63,64)$, though more markedly in regions related with food sensing and reward, and in the hypothalamus. The current evidence also supports the concept that insufficient metabolic hyperactivation in orbitofrontal inhibitory regions may predict greater food dependency (64), possibly because the degree of hypermetabolism observed in sensing and reward-related regions is not sufficiently balanced by areas of executive function. The observation that an inhibitory cognitive task reduces brain glucose uptake in all regions, resulting in lower hunger ratings, further supports the existence of a metabolic network in which cognition prevails (metabolically) over anticipated reward. Interestingly, one study showing that BMI and cognition were inversely related (65) highlighted that low frontal glucose metabolism was associated with both BMI (negative) and cognitive function (positive), involving domains beyond inhibitory glucose metabolism, for example memory and recall, executive function, verbal and non-verbal intelligence quotients. So far, we are left with the dual hypothesis that obesity may independently affect frontal metabolism and cognition or that dysfunctional prefrontal metabolism due to for example cognitive disease may fail to inhibit overeating, contributing to obesity. Animal studies support both possibilities. On one side, lesions of the hippocampus lead to overeating $(67,68)$, and mouse models of Alzheimer's disease (AD) type pathology show overeating compared to controls (69). On the other hand, high-fat feeding 
in these genetically predisposed animals accelerates neurodegeneration and cognitive decline. Metabolically, a high-fat diet elevated brain glucose uptake in middleaged mice, but this elevation was blunted in the $\mathrm{AD}$ type model and followed by a remarkable metabolic and cognitive fall throughout aging (69). Exposure to a high-fat diet or maternal obesity during early life development predicts premature cognitive decline and obesity along the lifespan in humans $(7,8,16,17,18$, 20). In a minipig model, such exposure led to a marked elevation in brain glucose uptake in the initial post-natal period, due to hyperglycemia, followed by a rapid decline resulting in brain hypometabolism in later life stages (70). Accordingly, brain glycogen levels were depleted in adult offspring born to high-fat diet mothers.

The above studies suggest that, as we attempt to establish cerebral glucose metabolism as predictor or hallmark of disease, it is fundamental to consider that brain glucose uptake may vary depending on brain regions, disease type, staging, duration and severity. This is supported by for example mouse models of AD that are characterized by different temporal patterns of disease development, as brain metabolism was found to be deficient in animals showing advanced neurodegeneration and cognitive decline (71) already at 7 months of age, but not in 3xTg mice showing only mild signs of dysfunction and structural loss at 8 months of age (69). Along these spectra, brain hypermetabolism can appear as an early trait, occurring during early- or mid-life periods and vanishing along aging or advanced disease or after prolonged high-fat diet exposure. Reinforcing this conclusion, a study in patients with different degrees of cognitive impairment has shown that cerebral glucose metabolism was high in subjects with mild disease, and low in advanced disease compared to healthy controls (45). The authors speculate that brain hypermetabolism may serve as transient compensatory reaction to the initial neurodegenerative insult, but is progressively replaced by hypometabolism, as tissue loss becomes more severe in the chronic situation. The authors surmise that in spite of being compensatory, the initial glucose excess may overstimulate and exhaust neural networks, accelerating the degenerative process. The same compensatory theory was suggested to explain the preservation of cognitive function in a study in morbidly obese women, showing brain hypermetabolism (54). Again these authors refer to the initial phase of neurodegeneration, in which inhibitory synapses are first destroyed, and excitatory synapses prevail with increased local activity (72), which may justify brain hypermetabolism in obese patients.
Figure 2 illustrates the above concepts, providing a hypothetical time-course of brain glucose uptake along the progression of life, in relation to cognitive disease with and without obesity.

As potential mechanisms whereby an excessive uptake of glucose by the brain can result in a simultaneous dysregulation of appetite, systemic metabolism and cognitive function, brain-derived neurotrophic factor (BDNF) stems as a credible candidate. BDNF has been implicated in the pathogenesis of obesity, type 2 diabetes, and neurodegeneration $(73,74,75)$. BDNF deficiency is a recognized correlate of memory impairment and has been described in patients with obesity and type 2 diabetes (76). The administration of BDNF in animal models was shown to improve the control of food intake and weight loss, peripheral glucose homeostasis, neuropreservation and cognition $(77,78,79,80,81)$. Few studies have addressed the relationship linking BDNF production and brain glucose uptake. Elegant human experiments, using arterial-venous catheterization across the brain, have documented that BDNF release by the human brain is suppressed by brain glucose overexposure, that is, high blood glucose levels during a hyperglycemic clamp (73). In Zucker fatty rats, we have shown that brain glucose uptake, as measured by FDG PET imaging correlates inversely with circulating levels of BDNF (59). The relationship was stronger in young, pre-obese (but already glucose intolerant) animals, and we confirmed the dependency of BDNF on glucose levels already in human fetal cord plasma. Since the latter were in turn dependent on maternal glycemia at the time of delivery, we suggested that the establishment of optimal glycemic conditions at the time of birth might be a unique opportunity to protect cognitive and metabolic health.

\section{Emerging mechanistic hypotheses leading to preventive perspectives}

Animal studies have shown that some of the actions of glucose in the brain occur only in the presence of concurrent insulin delivery (82). Secreted insulin can reach the brain and its receptors are present in most brain regions, as reviewed by Blazquez et al. and Ghasemi et al. $(83,84)$. Insulin is a growth and metabolic regulator, whose cerebral actions have been implicated in the pathogenesis of obesity (suppression of appetite (85), regulation of adipose tissue lipolysis and lipogenesis $(41,86))$, type 2 diabetes (modulation of endogenous glucose production and glucose levels $(37,38)$, and of pancreatic insulin

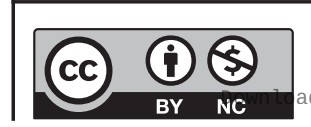


secretion $(87,88,89))$, and Alzheimer's disease (90). Most of these actions are lost in experimental models of obesity induced by high fat feeding (91). The role of insulin on brain glucose metabolism remains to be fully established. As detailed in the previous sections, compared to fasting, the induction of euglycemic hyperinsulinemia does not provoke any change in brain glucose uptake in healthy individuals, whereas it elicits a positive response in obese or glucose-intolerant patients. However, it is of note that the euglycemic-hyperinsulinemic clamp technique does not allow to dissect the direct role of insulin on the brain from the many peripheral actions occurring concomitantly. It is also important to recognize that insulin clamp studies prevent the reduction of glucose levels, which is the most important insulin effect in physiological conditions. Intranasal insulin injections have been recently used as a way to dissect central insulin roles, with translational perspectives in humans. Animal studies have shown that when insulin is delivered to the brain via the intranasal route, brain glucose uptake is reduced, mainly due to a centrally mediated hypoglycemic effect of the hormone (69). According to this, brain insulin resistance can be defined as failure of insulin to suppress brain glucose uptake, which is coherent with the finding of high glucose uptake under human euglycemic insulin clamp conditions. Comparing healthy lean mice of different ages, we observed that the central hypometabolic action of insulin was significant in adult and old mice, but was not present in early post-natal life $(69,92)$. It is plausible that brain glucose suppressing signals are not yet operative in the first period of life, to ensure sufficient energy provisions during this demanding phase of rapid brain growth. Interestingly, mice born to high fat fed dams showed brain hypersensitivity to insulin in this early period and brain insulin resistance during (mid-life) adulthood (92), and minipigs born to high fat fed sows showed greater brain-specific insulin receptor density few days post-natally, followed by deficiency in insulin receptors and insulin-dependent glucose transporters (GLUT4) in the cortex and hypothalamus (70). Also the combination of high fat dieting and AD type pathology in mice is characterized by an absent response of brain glucose metabolism to intranasal insulin. These mice showed similar brain hypermetabolism during fasting and during insulin stimulation. Again this trait was clearly detectable during mid-life, but not after aging. In these mice, the chronic administration of intranasal insulin, starting in early adulthood resulted in a normalized mid-life brain metabolism and insulin response, together with a full preservation of cognitive function and hippocampus size throughout the lifespan (69). Insulin therapy also reduced food intake, body weight and peripheral glucose levels. Brain PET imaging studies with intranasal insulin in obese humans are lacking. In non-obese patients with clinically confirmed symptomatic cognitive disease, the chronic administration of intranasal insulin improved memory and slowed the decline in brain metabolism linked to tissue degeneration (93). Subsequent observations by the same authors indicate that the insulin formulation may importantly interfere with the outcome, as the effects of rapid insulin on cognition could be reproduced, whereas long-acting insulin was less effective and not consistent (93); unfortunately, PET imaging was not carried out in these comparative studies. In the field of obesity, acute intranasal insulin studies addressing functional responses by magnetic resonance imaging, systemic insulin sensitivity or hunger ratings $(94,95)$ support the suppressive effects of intranasal insulin on peripheral glucose levels, hypothalamic activity, and appetite control in humans. These metabolic effects await for chronic intervention trials to be tested for longer term efficacy and safety in obese patients.

Omics technologies represent another field of intensive investigation due to their potential to identify and/or confirm early biomarkers and mechanistic links related to obesity and neurodegenerative disease. Among them, the study of the microbiome emerges as a promising candidate for treatment, since pioneer trials with probiotics or fecal transplant have shown some benefit in dysmetabolic and Alzheimer's patients $(96,97)$, and probiotics have been safely administered to pregnant women or infants (98), opening an opportunity of primary prevention $(99,100)$. Many studies have shown differences in microbiota composition between lean and obese individuals $(101,102,103)$. Seminal studies have produced first evidence in human Alzheimer's pathology $(104,105)$. In one animal study in which brain glucose metabolism was measured, we have shown that microbiota composition differs in mice fed a high fat diet and in mice with genetically determined AD type pathology in the early course of the disease, leading to additive effects when the two conditions are combined (106). We have also documented that fecal and serum metabolomes were different between groups and that numerous metabolites correlated with relative bacteria abundances. Some of these bacteria were associated with cognitive dysfunction and brain metabolism. Emerging bacteria patterns include depletion of Bifidobacterium, and overabundance Turicibacteraceae, Christensenellaceae, Anaeroplasmataceae and Ruminococcaceae. Emerging metabolites were amino

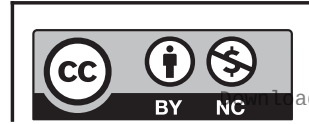

This work is licensed under a Creative Commons Attribution-NonCommercial 4.0 International License. ded from Bioscientifica.com at 04/26/2023 12:37:54PM 
acids (leucine, isoleucine, glycine), ketone bodies, lactate, TMA-TMAO, and inflammatory indicators, all present in greater concentrations in diseased cases, together with a reduction in fatty acids. It is of translational interest that several of these metabolites were recently reported to be elevated in morbidly obese humans in association with an elevation in brain glucose metabolism (55).

Bariatric surgery represents a model of treatment in which all the elements above improve in combination (55, $107,108)$. It can therefore substantiate their involvement, though it does not dissect and provide in itself a causeeffect demonstration for each factor. Interestingly, bariatric surgery leads to an amelioration in cognitive function, appetite regulation and weight loss. Brain glucose hypermetabolism and the related circulating metabolites are normalized after the intervention $(52,54)$. Transplantation of human microbiota following bariatric surgery into mice suggests that bacterial changes induced by the gastrointestinal operation are partly responsible for the effects of surgery on circulating metabolites (108). Though the gut-brain axis is focus of intensive investigation, and the microbiota can potentially influence brain development, structure and function by several mechanisms, a direct effect of bacteria or their metabolic products on brain glucose metabolism has not been yet clarified in the published literature.

\section{Technical considerations}

There are a number of technical differences between PET imaging studies, involving image acquisition and processing that might influence the interpretation of results in the reports quoted in this review; the available information is summarized in Table 1. First, dynamic scans allow to follow the progressive concentration of ${ }^{18} \mathrm{FDG}$ radioactivity in the brain over time (time-activity curve) starting from tracer injection, whereas static images provide a single-activity value, usually delayed from injection to avoid the initial blood flow-dependent phase, and primarily reflect the accumulation of ${ }^{18} \mathrm{FDG}$ that is induced by metabolic needs. Dynamic images allow sophisticated mathematical for example graphical and compartmental modeling (based on the changing levels of tissue to blood activities over time, to generate one or multiple rate constants) compared to simpler approaches and parameters that can be reliably obtained by static images (e.g. the ratio of tissue to injected dose per unit of body weight, or - if an input function is available - the ratio of tissue to integrated blood activity). In these ways, dynamic and static scanning modes provide different but tightly correlated absolute values of brain glucose uptake and are both widely accepted and valid. However, when complex modeling (suited to dynamic imaging) is forcefully applied to a static image in the attempt to go beyond the simple parameters it can provide, several assumptions are required, including the use of a set of predefined and fixed rate constants, introducing some degree of arbitrariness in the results. Interestingly, this method led to low absolute frontal glucose uptake values in obese individuals (65), as opposed to either normal or tendentially elevated values in conservative approaches. Second, the input function (i.e. the tracer concentration that is available in blood for tissue extraction, as used in the above computations) should ideally be obtained by arterial blood sampling. To circumvent this invasive procedure, several groups have replaced arterial with arterialized (by heating pad or box) venous blood, which is accepted and common practice in metabolic (non-imaging) insulin clamp studies since their origin (109). In theory, oxygen saturation should be measured to confirm proper arterialization of venous blood; de facto, this measurement is rarely pursued. In few studies in Table 1, an image-derived input function (from cardiac cavities or carotid images) has been used, to avoid any frequent blood sampling, especially during the peak-phase after tracer injection, with few cross-check blood samples needed. In other few cases, normalization of regional to whole brain values was done in place of any mathematical modeling $(66,93)$ or in addition to the quantification of brain glucose uptake (63). Normalization requires caution as it can introduce a degree of cross-dependency and amplification of results. Third, different scanners and reconstruction methods are likely to lead to different absolute values. In recent years, iterative reconstruction methods (approximating the real image by an iterative process) have replaced the (raw data-driven) filtered-backprojection, leading to images that are of superior visual quality, but less consistently accurate. PET scanner and reconstruction affect image resolution, influencing the extent of partial volume/ spill-over effects (contamination from surrounding tissue) in brain sub-regions whose size is close to or lower than the resolution. Though this error can be satisfactorily corrected in post-processing, such operation was not clearly reported in most Table 1 studies. Fourth, reconstructed images reflect radioactivity concentrations in $\mathrm{kBq} / \mathrm{cc}$, which can be converted into metabolic maps, by applying mathematical modeling to each image voxel https://ec.bioscientifica.com https://doi.org/10.1530/EC-19-0348 (c) 2019 The authors Published by Bioscientifica Ltd
This work is licensed under a Creative Commons Attribution-NonCommercial 4.0 International License. ded from Bioscientifica.com at 04/26/2023 12:37:54PM 
Table 1 Technical features in PET image acquisition, reconstruction and analysis methods.

\begin{tabular}{|c|c|c|c|c|}
\hline & & Scanner & $\begin{array}{l}\text { Glucose uptake } \\
\text { quantification }\end{array}$ & Normalization \\
\hline Reference & PET acquisition & $\begin{array}{l}\text { Reconstruction } \\
\text { Resolution }\end{array}$ & $\begin{array}{l}\text { Input function } \\
\text { Lumped constant (LC) }\end{array}$ & $\begin{array}{l}\text { Analysis method } \\
\text { Statistical correction }\end{array}$ \\
\hline $\begin{array}{l}\text { Hirvonen } \\
\text { et al. (42) }\end{array}$ & Dynamic & $\begin{array}{l}\text { GE Advanced PET camera } \\
- \\
\text { Resolution of parametric } \\
\text { image } 12 \mathrm{~mm} \text { FWHM }\end{array}$ & $\begin{array}{l}\text { CMRglu by Gjedder- } \\
\text { Patlak plot } \\
\text { Arterial input function } \\
\mathrm{LC}=0.52\end{array}$ & $\begin{array}{l}\text { SPM analysis + ROI-based } \\
\text { analysis } \\
\text { Significance voxel level } \\
\text { uncorrected } P<0.05 \text {, cluster } \\
\text { level corrected } P<0.05\end{array}$ \\
\hline $\begin{array}{l}\text { Bingham } \\
\text { et al. (49) }\end{array}$ & $\begin{array}{l}\text { Dynamic } \\
\text { 90-min }\end{array}$ & $\begin{array}{l}\text { Siemens/CTI ECAT 951R } \\
\text { tomograph } \\
\text { FBP reconstruction } \\
\text { Resolution } 8.5 \mathrm{~mm} \text { FWHM }\end{array}$ & $\begin{array}{l}\text { CMRglu by Gjedder- } \\
\text { Patlak plot } \\
\text { Arterial input function } \\
\text { LC }=0.52\end{array}$ & $\begin{array}{l}\text { Whole-brain uptake as } \\
\text { confounding covariate } \\
\text { SPM analysis + ROI-based } \\
\text { analysis } \\
\text { Significance at clusters level } \\
\text { uncorrected } P<0.001\end{array}$ \\
\hline $\begin{array}{l}\text { Hasselbach } \\
\text { et al. (50) }\end{array}$ & $\begin{array}{l}\text { Dynamic } \\
\text { 45-min or } \\
\text { 95-min }\end{array}$ & $\begin{array}{l}\text { Therascan } 3128 \text { PET camera } \\
- \\
\text { Plane resolution } 20 \mathrm{~mm}\end{array}$ & $\begin{array}{l}\text { CMRglu by } 3 \mathrm{~K} \text { and } 4 \mathrm{~K} \\
\text { models } \\
\text { Arterial input function } \\
\text { LC experimentally } \\
\text { determined }\end{array}$ & - \\
\hline $\begin{array}{l}\text { Cranston } \\
\text { et al. (51) }\end{array}$ & $\begin{array}{c}\text { Dynamic } \\
60-\mathrm{min}\end{array}$ & $\begin{array}{l}\text { Siemens/CTI ECAT 951R } \\
\text { tomograph } \\
- \\
\text { Resolution } 8.5 \mathrm{~mm}\end{array}$ & $\begin{array}{l}\text { CMRglu by } 4 \mathrm{~K} \text { model } \\
\text { Arterial input function } \\
\mathrm{LC}=0.52\end{array}$ & $\begin{array}{l}\text { ROI-based analysis } \\
\text { - }\end{array}$ \\
\hline $\begin{array}{l}\text { Tuulari } \\
\text { et al. (52) }\end{array}$ & $\begin{array}{l}\text { Dynamic } \\
40-\text { min }\end{array}$ & $\begin{array}{l}\text { GE Advanced PET camera } \\
\text { Reconstruction using Hann } \\
\text { filter with cut-off frequency } \\
\text { of } 0.5 \text { and MRP method } \\
\text { Resolution of parametric } \\
\text { images } 10 \mathrm{~mm} \text { FWHM }\end{array}$ & $\begin{array}{l}\text { CMRglu by Gjedder- } \\
\text { Patlak plot } \\
\text { Arterial input function } \\
\text { LC }=0.80 \text { or } \\
\text { experimentally } \\
\text { determined }\end{array}$ & $\begin{array}{l}- \\
\text { SPM analysis + ROI-based } \\
\text { analysis } \\
\text { Voxel level analysis FDR } \\
\text { corrected, cluster level } \\
\text { uncorrected }\end{array}$ \\
\hline $\begin{array}{l}\text { Wang } \\
\text { et al. (53) }\end{array}$ & Static 20-min & $\begin{array}{l}\text { CTI-931 tomograph } \\
\text { (Computer Technologies) } \\
- \\
\text { Resolution } 6.5 \mathrm{~mm} \text { FWHM, } \\
\text { final resolution of parametric } \\
\text { image } 16 \mathrm{~mm} \text { FWHM }\end{array}$ & $\begin{array}{l}\text { CMRglu computed using } \\
\text { published k constants } \\
(4 \mathrm{~K}) \\
\text { Arterial input function } \\
\mathrm{LC}=0.52\end{array}$ & $\begin{array}{l}\text { SPM analysis } \\
\text { Significance at voxel level } \\
\text { uncorrected } P<0.003\end{array}$ \\
\hline $\begin{array}{l}\text { Marques } \\
\text { et al. (54) }\end{array}$ & Static 15-min & $\begin{array}{l}\text { Siemens/CTI PET/CT Biograph } \\
\text { 3D-OSEM reconstruction } \\
\text { Final resolution } 8 \mathrm{~mm} \text { FWHM }\end{array}$ & $\begin{array}{l}\text { Not calculated, only } \\
\text { statistics reported }\end{array}$ & $\begin{array}{l}\text { - } \\
\text { SPM analysis } \\
\text { Voxel level analysis with } \\
\text { FWE correction }\end{array}$ \\
\hline $\begin{array}{l}\text { Rebelos } \\
\text { et al. (55) }\end{array}$ & $\begin{array}{l}\text { Dynamic } \\
40-\text { min }\end{array}$ & $\begin{array}{l}\text { GE Advanced PET camera } \\
\text { Reconstruction using Hann } \\
\text { filter with cut-off frequency } \\
\text { of } 0.5 \text { and MRP method } \\
\text { Resolution of parametric } \\
\text { images } 10 \mathrm{~mm} \text { FWHM }\end{array}$ & $\begin{array}{l}\text { CMRglu by Gjedder- } \\
\text { Patlak plot } \\
\text { Arterial input function } \\
\text { LC }=0.65\end{array}$ & $\begin{array}{l}\text { SPM analysis + ROI-based } \\
\text { analysis } \\
\text { Cluster level analysis with } \\
\text { FDR correction }\end{array}$ \\
\hline $\begin{array}{l}\text { Bahri } \\
\text { et al. (57) }\end{array}$ & $\begin{array}{c}\text { Dynamic } \\
55-\min \end{array}$ & $\begin{array}{l}- \\
\text { FBP reconstruction } \\
\text { Resolution } 8.5 \mathrm{~mm} \text { FWHM }\end{array}$ & $\begin{array}{l}\text { CMRglu by } 3 \mathrm{~K} \text { model, } \\
\text { Patlak plot for } \\
\text { calculation of } \\
\text { parametric map, and } \\
\text { spectral analysis } \\
\text { Arterial input function } \\
\text { LC }=0.45\end{array}$ & $\begin{array}{l}\text { SPM analysis + ROI-based } \\
\text { analysis } \\
\text { Threshold for cluster size } \\
100 \text { voxels, FDR correction }\end{array}$ \\
\hline $\begin{array}{l}\text { Liistro } \\
\text { et al. (58) }\end{array}$ & Static $20-\mathrm{min}$ & $\begin{array}{l}\text { YAP(S)PET microPET (ISE s.r.I.) } \\
\text { OSEM reconstruction } \\
\text { Resolution } 1 \mathrm{~mm} \text { FWHM }\end{array}$ & $\begin{array}{l}\text { FURglu } \\
\text { Image-derived input } \\
\text { function } \\
\text { _ }\end{array}$ & $\begin{array}{l}\text { Spillover correction of the } \\
\text { image-derived input curves } \\
\text { ROI-based analysis } \\
\text { _ }\end{array}$ \\
\hline $\begin{array}{l}\text { Guzzardi } \\
\text { et al. (59) }\end{array}$ & Static $20-$ min & $\begin{array}{l}\text { YAP(S)PET microPET (ISE s.r.I.) } \\
\text { OSEM reconstruction } \\
\text { Resolution } 1 \mathrm{~mm} \text { FWHM }\end{array}$ & $\begin{array}{l}\text { SUVglu } \\
- \\
-\end{array}$ & $\begin{array}{l}\text { ROI-based analysis } \\
\text { - }\end{array}$ \\
\hline
\end{tabular}

https://ec.bioscientifica.com

https://doi.org/10.1530/EC-19-0348
(C) 2019 The authors Published by Bioscientifica Ltd

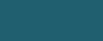


Table 1 Continued

\begin{tabular}{|c|c|c|c|}
\hline & & Scanner & $\begin{array}{l}\text { Glucose uptake } \\
\text { quantification }\end{array}$ \\
\hline Reference & PET acquisition & $\begin{array}{l}\text { Reconstruction } \\
\text { Resolution }\end{array}$ & $\begin{array}{l}\text { Input function } \\
\text { Lumped constant (LC) }\end{array}$ \\
\hline $\begin{array}{l}\text { Wang } \\
\text { et al. (62) }\end{array}$ & $\begin{array}{l}\text { Static } \\
\text { 20-min }\end{array}$ & $\begin{array}{l}\text { Siemens HR + PET scanner } \\
- \\
\text { Resolution } 4.5 \text { mm FWHM, } \\
\text { resolution of parametric } \\
\text { image } 16 \mathrm{~mm} \text { FWHM }\end{array}$ & $\begin{array}{l}\text { CMRglu by using } \\
\text { published k constants } \\
(4 \mathrm{~K}) \\
\text { Arterialized plasma input } \\
\text { function } \\
\text { LC }=0.52\end{array}$ \\
\hline $\begin{array}{l}\text { Wang } \\
\text { et al. (63) }\end{array}$ & $\begin{array}{l}\text { Static } \\
\text { 20-min }\end{array}$ & $\begin{array}{l}\text { Siemens HR+ PET scanner } \\
- \\
\text { Resolution } 4.5 \mathrm{~mm} \text { FWHM, } \\
\text { resolution of parametric } \\
\text { image } 16 \mathrm{~mm} \text { FWHM }\end{array}$ & $\begin{array}{l}\text { CMRglu by using } \\
\text { published } \mathrm{k} \text { constants } \\
(4 \mathrm{~K}) \\
\text { Arterialized plasma input } \\
\text { function } \\
\mathrm{LC}=0.52\end{array}$ \\
\hline $\begin{array}{l}\text { Guzzardi } \\
\text { et al. (64) }\end{array}$ & $\begin{array}{l}\text { Dynamic } \\
\text { 40-min }\end{array}$ & $\begin{array}{l}\text { GE discovery VCT PET/CT } \\
\text { Scanner } \\
\text { OSEM reconstruction } \\
\text { Resolution } 5.8 \text { mm FWHM }\end{array}$ & $\begin{array}{l}\text { CMRglu by Gjedder- } \\
\text { Patlak plot } \\
\text { Image-derived input } \\
\text { function }\end{array}$ \\
\hline $\begin{array}{l}\text { Volkow } \\
\text { et al. (65) }\end{array}$ & $\begin{array}{l}\text { Static } \\
\text { 20-min }\end{array}$ & $\begin{array}{l}\text { Siemens/CTI ECAT HR+ PET } \\
\text { scanner } \\
- \\
\text { Resolution } 4.5 \mathrm{~mm} \text { FWHM, } \\
\text { resolution of parametric } \\
\text { image } 16 \mathrm{~mm} \text { FWHM }\end{array}$ & $\begin{array}{l}\text { CMRglu by using } \\
\text { published k constants } \\
(4 \mathrm{~K}) \\
\text { Arterialized plasma input } \\
\text { function } \\
\text { LC }=0.52\end{array}$ \\
\hline $\begin{array}{l}\text { Thanos } \\
\text { et al. (66) }\end{array}$ & $\begin{array}{l}\text { Static } \\
\text { 80-min }\end{array}$ & $\begin{array}{l}\text { Siemens R4 UPET tomograph, } \\
\text { FBP and OSEM3D/MAP } \\
\text { reconstruction methods } \\
\text { Resolution } 2 \mathrm{~mm} \text { FWHM. }\end{array}$ & $\begin{array}{l}\text { Not reported, only } \\
\text { statistics reported }\end{array}$ \\
\hline $\begin{array}{l}\text { Sanguinetti } \\
\text { et al. (69) }\end{array}$ & $\begin{array}{l}\text { Dynamic } \\
60-\text { min }\end{array}$ & $\begin{array}{l}\text { IRIS PET/CT microPET-CT } \\
\text { tomograph (Inviscan SAS) } \\
\text { OSEM reconstruction } \\
\text { Resolution } 1 \mathrm{~mm} \text { FWHM }\end{array}$ & $\begin{array}{l}\text { SUVglu } \\
-\end{array}$ \\
\hline $\begin{array}{l}\text { Sanguinetti } \\
\text { et al. (70) }\end{array}$ & Static & $\begin{array}{l}\text { Siemens ECAT HR+ } \\
\text { tomograph } \\
\text { FBP reconstruction } \\
\text { Resolution } 5-8 \mathrm{~mm} \text { FWHM }\end{array}$ & $\begin{array}{l}\text { FURglu } \\
\text { Image-derived input } \\
\text { function } \\
\text { - }\end{array}$ \\
\hline $\begin{array}{l}\text { Bouter } \\
\text { et al. (71) }\end{array}$ & $\begin{array}{l}\text { Static } \\
\text { 20-min }\end{array}$ & $\begin{array}{l}\text { Small animal } 1 \text { Tescal } \\
\text { nanoScan PET/MRI (Mediso) } \\
- \\
-\end{array}$ & SUVglu \\
\hline $\begin{array}{l}\text { Sanguinetti } \\
\text { et al. (92) }\end{array}$ & $\begin{array}{l}\text { Dynamic } \\
60-\text { min }\end{array}$ & $\begin{array}{l}\text { IRIS PET/CT microPET-CT } \\
\text { tomograph (Inviscan SAS) } \\
\text { OSEM reconstruction } \\
\text { Resolution } 1 \mathrm{~mm} \text { FWHM }\end{array}$ & $\begin{array}{l}\text { SUVglu } \\
-\end{array}$ \\
\hline Craft et al. (93) & $\begin{array}{l}\text { Static } \\
15-\min \end{array}$ & $\begin{array}{l}\text { GE Advance PET scanner } \\
\text { FBP reconstruction } \\
\text { Resolution } 5 \text { mm FWHM }\end{array}$ & $\begin{array}{l}\text { Not reported, only } \\
\text { statistics reported }\end{array}$ \\
\hline
\end{tabular}

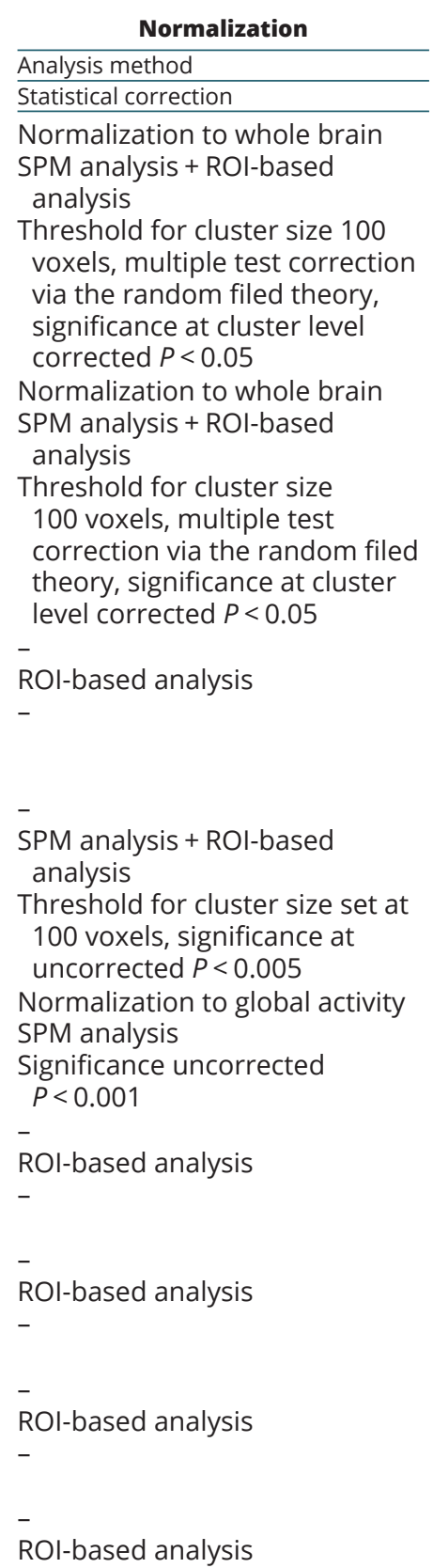

Normalization to cerebellar and pontine values

SPM analysis + ROI-based analysis Voxel wise analysis corrected for multiple comparison

The hyphen (-) indicates that the information was not reported and not obtained by previous publications.

$3 \mathrm{~K}$ and $4 \mathrm{~K}$, pharmacokinetic three-compartment three- or four-rate-constant models; CMRglu, cerebral metabolic rate of glucose calculated as FDG rate of extraction (ki) multiplied by plasma glucose concentration; FBP, filtered back projection; FDR, false discovery rate; FURglu, glucose fractional uptake rate (ratio of tissue radioactivity concentration at time $\mathrm{T}$ and integral of plasma activity from time 0 to $\mathrm{T}$ ) multiplied by plasma glucose concentration; FWE, family wise error; FWHM, full width half maximum; MRP, median root prior; OSEM, ordered subsets expectation maximization; ROI, region of interest; SPM, standardized parametric mapping; SUVglu, standardized uptake value (ratio of tissue radioactivity concentration at time T and administered dose at time of injection divided by body weight) multiplied by plasma glucose concentration.

https://ec.bioscientifica.com

https://doi.org/10.1530/EC-19-0348 (c) 2019 The authors Published by Bioscientifica Ltd

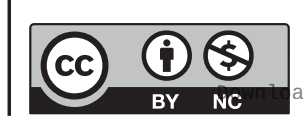

This work is licensed under a Creative Commons Attribution-NonCommercial 4.0 International License. ded from Bioscientifica.com at $04 / 26 / 2023$ 12:37:54PM 


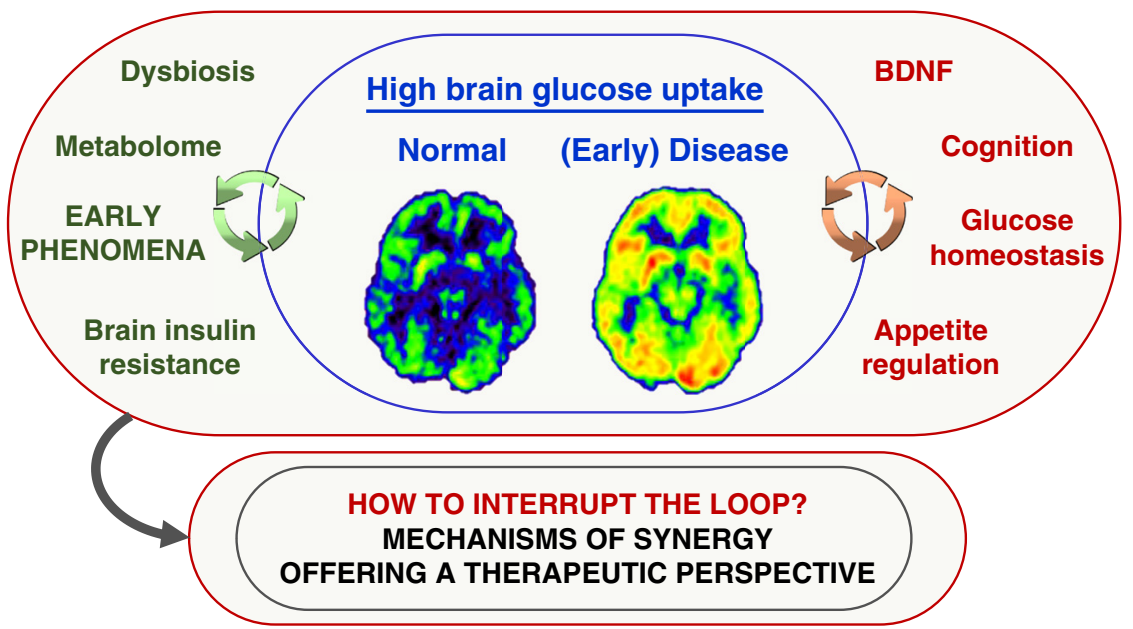

\section{Figure 3}

The central panel highlights that high brain glucose uptake occurs in selected stages of metabolic and neurodegenerative diseases, and may be offensive and/or defensive. The right panel addresses conditions that might be fostered by brain hypermetabolism, whereas the left panel lists early phenomena that might be promising prevention targets.
(46, 47, 110). Then, statistical analyses can be done automatically on a voxel-by-voxel basis, after brain alignment to a reference space (statistical parametric mapping (SPM)) across all brain voxels. In this multiple comparisons approach it is important to correct for the risk of false positive findings, by applying e.g. familywise error or false discovery rate corrections. To reduce the impact of interdependency, one may restrict these corrections to a selected number of voxels in a given target region (small volume correction) or extract values from few larger regions of interest, corresponding to anatomically or functionally meaningful areas of the brain, and/or utilize non-SPM based analysis. Original images (kBq/ cc) can also be used to extract tissue time-activity-curves from brain subregions and apply mathematical modeling outside of the image domain (non-parametric image and non-SPM based analysis), reducing the noise related to the modeling of time-activity-curves in each very small voxel, though introducing some degree of operator dependency in the definition of the region of interest.

Deeper technical insights are beyond the scope of this review, and can be found in (111), focusing on the relevance of a priori validation in PET data simplification, and in $(112,113,114)$, covering statistical concepts that are common to MRI, PET, and other neuroimaging modalities.

\section{Conclusions}

In this review, we have addressed brain glucose metabolism determinations by FDG PET imaging, as a potential unifying marker in the synergy linking obesity and cognitive disease. Figure 3 provides a graphic representation of the following conclusions, as supported by the current evidence: (a) brain glucose metabolism undergoes changes across the lifespan, increasing in first life years and declining from late childhood through aging in the normal situation; (b) compared to healthy individuals, brain glucose metabolism is high during mid-life in adults with obesity or with mild cognitive dysfunction and in animal models of AD pathology fed a high-fat diet or animal models of metabolic syndrome, as well as during early life days in offspring born to obese mothers; (c) most observations indicate that brain hypermetabolism may be a transient phenomenon, eventually evolving toward normal or low values during life or disease progression; (d) associative studies suggest that brain hypermetabolism predicts low BDNF levels, hepatic and whole body insulin resistance, food desire and an unfavorable balance between anticipated reward and cognitive control; (e) the effect of (intranasal) insulin is to reduce brain glucose exposure, that is, brain insulin resistance manifests as failure of insulin to achieve this suppression; (f) according to this definition, brain insulin resistance occurs in obese individuals, in mice born to obese mothers, and in mice with AD pathology when combined with high fat feeding; (g) emerging mechanistic links, showing summative alterations in AD, obesity and high-fat diets involve the microbiota and the metabolome, which correlate with brain metabolism and cognition. Though brain hypermetabolism is considered a potential compensatory reaction against initial brain damage, its consequences may still be deleterious. Research priorities in this area require clarification of whether brain hypermetabolism, and its reversal play a causative or protective role in obesity, neurodegeneration and their combination, and whether metabolites or bacteria or hormones (insulin and beyond) can be an effective strategy to prevent or mitigate the risk of neurodegeneration.

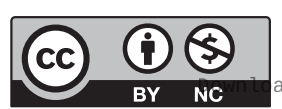




\section{Declaration of interest}

The authors declare that there is no conflict of interest that could be perceived as prejudicing the impartiality of this review.

\section{Funding}

This work relates to the Translational Project GUTMOM, supported by the JPI-HDHL-INTIMIC (JPI project ID INTIMIC-085) and the Italian Ministry of Education, University and Research (MIUR, decree number 946/2019, 15 May 2019) under the Eranet Cofund Grant Agreement Number 727565.

\section{References}

1 Shalev D \& Arbuckle MR. Metabolism and memory: obesity, diabetes, and dementia. Biological Psychiatry 201782 e81-e83. (https://doi. org/10.1016/j.biopsych.2017.09.025)

2 Profenno LA, Porsteinsson AP \& Faraone SV. Meta-analysis of Alzheimer's disease risk with obesity, diabetes, and related disorders. Biological Psychiatry 201067 505-512. (https://doi.org/10.1016/j. biopsych.2009.02.013)

3 Akomolafe A, Beiser A, Meigs JB, Au R, Green RC, Farrer LA, Wolf PA \& Seshadri S. Diabetes mellitus and risk of developing Alzheimer disease: results from the Framingham Study. Archives of Neurology 200663 1551-1555. (https://doi.org/10.1001/archneur.63.11.1551)

4 Chatterjee S, Peters SA, Woodward M, Mejia Arango S, Batty GD, Beckett N, Beiser A, Borenstein AR, Crane PK, Haan M, et al. Type 2 diabetes as a risk factor for dementia in women compared with men: a pooled analysis of 2.3 million people comprising more than 100,000 cases of dementia. Diabetes Care 201639 300-307. (https:// doi.org/10.2337/dc15-1588)

5 Dye L, Boyle NB, Champ C \& Lawton C. The relationship between obesity and cognitive health and decline. Proceedings of the Nutrition Society 201776 443-454. (https://doi.org/10.1017/S0029665117002014)

6 Courchesne E, Chisum HJ, Townsend J, Cowles A, Covington J, Egaas B, Harwood M, Hinds S \& Press GA. Normal brain development and aging: quantitative analysis at in vivo MR imaging in healthy volunteers. Radiology 2000216 672-682. (https://doi.org/10.1148/ radiology.216.3.r00au37672)

7 Bider-Canfield Z, Martinez MP, Wang X, Yu W, Bautista MP, Brookey J, Page KA, Buchanan TA \& Xiang AH. Maternal obesity, gestational diabetes, breastfeeding and childhood overweight at age 2 years. Pediatric Obesity 201712 171-178. (https://doi.org/10.1111/ijpo.12125)

8 Dabelea D \& Crume T. Maternal environment and the transgenerational cycle of obesity and diabetes. Diabetes 201160 1849-1855. (https://doi.org/10.2337/db11-0400)

9 Friedman JE. Obesity and gestational diabetes mellitus pathways for programming in mouse, monkey, and man-where do we go next? The 2014 Norbert Freinkel award lecture. Diabetes Care 201538 1402-1411. (https://doi.org/10.2337/dc15-0628)

10 Yuan C, Gaskins AJ, Blaine AI, Zhang C, Gillman MW, Missmer SA, Field AE \& Chavarro JE. Association between cesarean birth and risk of obesity in offspring in childhood, adolescence, and early adulthood. JAMA Pediatrics 2016170 e162385. (https://doi. org/10.1001/jamapediatrics.2016.2385)

11 Yan J, Liu L, Zhu Y, Huang G \& Wang PP. The association between breastfeeding and childhood obesity: a meta-analysis. BMC Public Health 201414 1267. (https://doi.org/10.1186/1471-2458-14-1267)

12 O'Tierney PF, Barker DJ, Osmond C, Kajantie E \& Eriksson JG. Duration of breast-feeding and adiposity in adult life. Journal of Nutrition 2009139 422S-425S. (https://doi.org/10.3945/ jn.108.097089)

13 Huh SY, Rifas-Shiman SL, Taveras EM, Oken E \& Gillman MW. Timing of solid food introduction and risk of obesity in preschool-aged children. Pediatrics 2011127 e544-e551. (https://doi. org/10.1542/peds.2010-0740)
14 Seach KA, Dharmage SC, Lowe AJ \& Dixon JB. Delayed introduction of solid feeding reduces child overweight and obesity at 10 years. International Journal of Obesity 201034 1475-1479. (https://doi. org/10.1038/ijo.2010.101)

15 Weber M, Grote V, Closa-Monasterolo R, Escribano J, Langhendries JP, Dain E, Giovannini M, Verduci E, Gruszfeld D, Socha $\mathrm{P}$, et al. Lower protein content in infant formula reduces BMI and obesity risk at school age: follow-up of a randomized trial. American Journal of Clinical Nutrition 201499 1041-1051. (https:// doi.org/10.3945/ajcn.113.064071)

16 Casas M, Chatzi L, Carsin AE, Amiano P, Guxens M, Kogevinas M, Koutra K, Lertxundi N, Murcia M, Rebagliato M, et al. Maternal prepregnancy overweight and obesity, and child neuropsychological development: two Southern European birth cohort studies. International Journal of Epidemiology 201342 506-517. (https://doi. org/10.1093/ije/dyt002)

17 Hinkle SN, Schieve LA, Stein AD, Swan DW, Ramakrishnan U \& Sharma AJ. Associations between maternal prepregnancy body mass index and child neurodevelopment at 2 years of age. International Journal of Obesity 201236 1312-1319. (https://doi.org/10.1038/ ijo.2012.143)

18 Hinkle SN, Sharma AJ, Kim SY \& Schieve LA. Maternal prepregnancy weight status and associations with children's development and disabilities at kindergarten. International Journal of Obesity $2013 \mathbf{3 7}$ 1344-1351. (https://doi.org/10.1038/ijo.2013.128)

19 Rivera HM, Christiansen KJ \& Sullivan EL. The role of maternal obesity in the risk of neuropsychiatric disorders. Frontiers in Neuroscience 20159 194. (https://doi.org/10.3389/fnins.2015.00194)

20 Tanda R, Salsberry PJ, Reagan PB \& Fang MZ. The impact of prepregnancy obesity on children's cognitive test scores. Maternal and Child Health Journal 201317 222-229. (https://doi.org/10.1007/ s10995-012-0964-4)

21 Brooks SJ, Benedict C, Burgos J, Kempton MJ, Kullberg J, Nordenskjold R, Kilander L, Nylander R, Larsson EM, Johansson L, et al. Late-life obesity is associated with smaller global and regional gray matter volumes: a voxel-based morphometric study. International Journal of Obesity 201337 230-236. (https://doi. org/10.1038/ijo.2012.13)

22 Ronan L, Alexander-Bloch AF, Wagstyl K, Farooqi S, Brayne C, Tyler LK, Cam-CAN \& Fletcher PC. Obesity associated with increased brain age from midlife. Neurobiology of Aging 2016 47 63-70. (https:// doi.org/10.1016/j.neurobiolaging.2016.07.010)

23 Benedict C, Brooks SJ, Kullberg J, Burgos J, Kempton MJ, Nordenskjold R, Nylander R, Kilander L, Craft S, Larsson EM, et al. Impaired insulin sensitivity as indexed by the HOMA score is associated with deficits in verbal fluency and temporal lobe gray matter volume in the elderly. Diabetes Care 201235 488-494. (https://doi.org/10.2337/dc11-2075)

24 Chugani HT. REVIEW: Metabolic imaging: a window on brain development and plasticity. Neuroscientist 19995 29-40. (https://doi. org/10.1177/107385849900500105)

25 Kuhl DE, Metter EJ, Riege WH \& Phelps ME. Effects of human aging on patterns of local cerebral glucose utilization determined by the [18F]fluorodeoxyglucose method. Journal of Cerebral Blood Flow and Metabolism 19822 163-171. (https://doi.org/10.1038/ jcbfm.1982.15)

26 Matsuda M, Liu Y, Mahankali S, Pu Y, Mahankali A, Wang J, DeFronzo RA, Fox PT \& Gao JH. Altered hypothalamic function in response to glucose ingestion in obese humans. Diabetes 199948 1801-1806. (https://doi.org/10.2337/diabetes.48.9.1801)

27 Berthoud HR, Munzberg H \& Morrison CD. Blaming the brain for obesity: integration of hedonic and homeostatic mechanisms. Gastroenterology 2017152 1728-1738. (https://doi.org/10.1053/j. gastro.2016.12.050)

28 Lennerz BS, Alsop DC, Holsen LM, Stern E, Rojas R, Ebbeling CB, Goldstein JM \& Ludwig DS. Effects of dietary glycemic index on brain regions related to reward and craving in men. American Journal

This work is licensed under a Creative Commons Attribution-NonCommercial 4.0 International License. ded from Bioscientifica.com at $04 / 26 / 2023$ 12:37:54PM 
of Clinical Nutrition 201398 641-647. (https://doi.org/10.3945/ ajcn.113.064113)

29 Zhang L, Han W, Lin C, Li F \& de Araujo IE. Sugar metabolism regulates flavor preferences and portal glucose sensing. Frontiers in Integrative Neuroscience 201812 57. (https://doi.org/10.3389/ fnint.2018.00057)

30 Tropeano G, Lucisano A, Liberale I, Barini A, Vuolo IP, Martino G, Menini E \& Dell'Acqua S. Insulin, C-peptide, androgens, and betaendorphin response to oral glucose in patients with polycystic ovary syndrome. Journal of Clinical Endocrinology and Metabolism $1994 \mathbf{7 8}$ 305-309. (https://doi.org/10.1210/jcem.78.2.8106616)

31 Goncalves P, Araujo JR \& Martel F. The effect of high glucose on SERT, the human plasmalemmal serotonin transporter. Nutritional Neuroscience 200811 244-250. (https://doi.org/10.1179/147683008X344156)

32 Berthoud HR \& Jeanrenaud B. Acute hyperinsulinemia and its reversal by vagotomy after lesions of the ventromedial hypothalamus in anesthetized rats. Endocrinology 1979105 146-151. (https://doi. org/10.1210/endo-105-1-146)

33 Rohner-Jeanrenaud F \& Jeanrenaud B. Consequences of ventromedial hypothalamic lesions upon insulin and glucagon secretion by subsequently isolated perfused pancreases in the rat. Journal of Clinical Investigation 198065 902-910. (https://doi.org/10.1172/JCI109744)

34 Goto Y, Carpenter RG, Berelowitz M \& Frohman LA. Effect of ventromedial hypothalamic lesions on the secretion of somatostatin, insulin, and glucagon by the perfused rat pancreas. Metabolism: Clinical and Experimental 198029 986-990. (https://doi. org/10.1016/0026-0495(80)90044-x)

35 Rohner F, Dufour AC, Karakash C, Le Marchand Y, Ruf KB \& Jeanrenaud B. Immediate effect of lesion of the ventromedial hypothalamic area upon glucose-induced insulin secretion in anaesthetized rats. Diabetologia 197713 239-242. (https://doi. org/10.1007/bf01219706)

36 Pocai A, Lam TK, Gutierrez-Juarez R, Obici S, Schwartz GJ, Bryan J, Aguilar-Bryan L \& Rossetti L. Hypothalamic K(ATP) channels control hepatic glucose production. Nature 2005434 1026-1031. (https:// doi.org/10.1038/nature03439)

37 Heni M, Wagner R, Kullmann S, Gancheva S, Roden M, Peter A, Stefan N, Preissl H, Haring HU \& Fritsche A. Hypothalamic and striatal insulin action suppresses endogenous glucose production and may stimulate glucose uptake during hyperinsulinemia in lean but not in overweight men. Diabetes 201766 1797-1806. (https://doi. org/10.2337/db16-1380)

38 Lam TK, Gutierrez-Juarez R, Pocai A \& Rossetti L. Regulation of blood glucose by hypothalamic pyruvate metabolism. Science 2005309 943-947. (https://doi.org/10.1126/science.1112085)

39 Carey M, Kehlenbrink S \& Hawkins M. Evidence for central regulation of glucose metabolism. Journal of Biological Chemistry 2013 288 34981-34988. (https://doi.org/10.1074/jbc.R113.506782)

40 Kreier F, Fliers E, Voshol PJ, Van Eden CG, Havekes LM, Kalsbeek A, Van Heijningen CL, Sluiter AA, Mettenleiter TC, Romijn JA, et al. Selective parasympathetic innervation of subcutaneous and intraabdominal fat - functional implications. Journal of Clinical Investigation 2002110 1243-1250. (https://doi.org/10.1172/JCI15736)

41 Scherer T, O'Hare J, Diggs-Andrews K, Schweiger M, Cheng B, Lindtner C, Zielinski E, Vempati P, Su K, Dighe S, et al. Brain insulin controls adipose tissue lipolysis and lipogenesis. Cell Metabolism 2011 13 183-194. (https://doi.org/10.1016/j.cmet.2011.01.008)

42 Hirvonen J, Virtanen KA, Nummenmaa L, Hannukainen JC, Honka MJ, Bucci M, Nesterov SV, Parkkola R, Rinne J, Iozzo P, et al. Effects of insulin on brain glucose metabolism in impaired glucose tolerance. Diabetes 201160 443-447. (https://doi.org/10.2337/db10-0940)

43 Ouellet M, Emond V, Chen CT, Julien C, Bourasset F, Oddo S, LaFerla F, Bazinet RP \& Calon F. Diffusion of docosahexaenoic and eicosapentaenoic acids through the blood-brain barrier: an in situ cerebral perfusion study. Neurochemistry International 200955 476-482. (https://doi.org/10.1016/j.neuint.2009.04.018)
44 Smith QR \& Nagura H. Fatty acid uptake and incorporation in brain: studies with the perfusion model. Journal of Molecular Neuroscience 200116 167-172; discussion 215-221. (https://doi.org/10.1385/ JMN:16:2-3:167)

45 Ashraf A, Fan Z, Brooks DJ \& Edison P. Cortical hypermetabolism in MCI subjects: a compensatory mechanism? European Journal of Nuclear Medicine and Molecular Imaging 201542 447-458. (https://doi. org/10.1007/s00259-014-2919-z)

46 Patlak CS \& Blasberg RG. Graphical evaluation of blood-to-brain transfer constants from multiple-time uptake data. Generalizations. Journal of Cerebral Blood Flow and Metabolism 19855 584-590. (https://doi.org/10.1038/jcbfm.1985.87)

47 Gunn RN, Gunn SR \& Cunningham VJ. Positron emission tomography compartmental models. Journal of Cerebral Blood Flow and Metabolism 200121 635-652. (https://doi. org/10.1097/00004647-200106000-00002)

48 Reivich M, Kuhl D, Wolf A, Greenberg J, Phelps M, Ido T, Casella V, Fowler J, Hoffman E, Alavi A, et al. The [18F]fluorodeoxyglucose method for the measurement of local cerebral glucose utilization in man. Circulation Research 197944 127-137. (https://doi. org/10.1161/01.res.44.1.127)

49 Bingham EM, Hopkins D, Smith D, Pernet A, Hallett W, Reed L, Marsden PK \& Amiel SA. The role of insulin in human brain glucose metabolism: an 18fluoro-deoxyglucose positron emission tomography study. Diabetes 200251 3384-3390. (https://doi. org/10.2337/diabetes.51.12.3384)

50 Hasselbalch SG, Knudsen GM, Videbaek C, Pinborg LH, Schmidt JF, Holm S \& Paulson OB. No effect of insulin on glucose blood-brain barrier transport and cerebral metabolism in humans. Diabetes 1999 48 1915-1921. (https://doi.org/10.2337/diabetes.48.10.1915)

51 Cranston I, Marsden P, Matyka K, Evans M, Lomas J, Sonksen P, Maisey M \& Amiel SA. Regional differences in cerebral blood flow and glucose utilization in diabetic man: the effect of insulin. Journal of Cerebral Blood Flow and Metabolism 199818 130-140. (https://doi. org/10.1097/00004647-199802000-00002)

52 Tuulari JJ, Karlsson HK, Hirvonen J, Hannukainen JC, Bucci M, Helmio M, Ovaska J, Soinio M, Salminen P, Savisto N, et al. Weight loss after bariatric surgery reverses insulin-induced increases in brain glucose metabolism of the morbidly obese. Diabetes 201362 2747-2751. (https://doi.org/10.2337/db12-1460)

53 Wang GJ, Volkow ND, Felder C, Fowler JS, Levy AV, Pappas NR, Wong CT, Zhu W \& Netusil N. Enhanced resting activity of the oral somatosensory cortex in obese subjects. NeuroReport 200213 1151-1155. (https://doi.org/10.1097/00001756200207020-00016)

54 Marques EL, Halpern A, Correa Mancini M, de Melo ME, Horie NC, Buchpiguel CA, Martins Novaes Coutinho A, Ono CR, Prando S, Santo MA, et al. Changes in neuropsychological tests and brain metabolism after bariatric surgery. Journal of Clinical Endocrinology and Metabolism 201499 E2347-E2352. (https://doi.org/10.1210/ jc.2014-2068)

55 Rebelos E, Immonen H, Bucci M, Hannukainen JC, Nummenmaa L, Honka MJ, Soinio M, Salminen P, Ferrannini E, Iozzo P, et al. Brain glucose uptake is associated with endogenous glucose production in obese patients before and after bariatric surgery and predicts metabolic outcome at follow-up. Diabetes, Obesity and Metabolism 201921 218-226. (https://doi.org/10.1111/dom.13501)

56 Park S, Hong SM \& Ahn IS. Long-term intracerebroventricular infusion of insulin, but not glucose, modulates body weight and hepatic insulin sensitivity by modifying the hypothalamic insulin signaling pathway in type 2 diabetic rats. Neuroendocrinology 200989 387-399. (https://doi.org/10.1159/000197974)

57 Bahri S, Horowitz M \& Malbert CH. Inward glucose transfer accounts for insulin-dependent increase in brain glucose metabolism associated with diet-induced obesity. Obesity 201826 1322-1331. (https://doi.org/10.1002/oby.22243) 
58 Liistro T, Guiducci L, Burchielli S, Panetta D, Belcari N, Pardini S, Del Guerra A, Salvadori PA \& Iozzo P. Brain glucose overexposure and lack of acute metabolic flexibility in obesity and type 2 diabetes: a PET-[18F] FDG study in Zucker and ZDF rats. Journal of Cerebral Blood Flow and Metabolism 201030 895-899. (https://doi.org/10.1038/jcbfm.2010.27)

59 Guzzardi MA, Sanguinetti E, Bartoli A, Kemeny A, Panetta D, Salvadori PA, Burchielli S \& Iozzo P. Elevated glycemia and brain glucose utilization predict BDNF lowering since early life. Journal of Cerebral Blood Flow and Metabolism 201838 447-455. (https://doi.org /10.1177/0271678X17697338)

60 Levin BE. Glucose-regulated dopamine release from substantia nigra neurons. Brain Research 2000874 158-164. (https://doi.org/10.1016/ s0006-8993(00)02573-7)

61 Umhau JC, Petrulis SG, Diaz R, Rawlings R \& George DT. Blood glucose is correlated with cerebrospinal fluid neurotransmitter metabolites. Neuroendocrinology 200378 339-343. (https://doi. org/10.1159/000074887)

62 Wang GJ, Volkow ND, Telang F, Jayne M, Ma J, Rao M, Zhu W, Wong CT, Pappas NR, Geliebter A, et al. Exposure to appetitive food stimuli markedly activates the human brain. Neuroimage 200421 1790-1797. (https://doi.org/10.1016/j.neuroimage.2003.11.026)

63 Wang GJ, Volkow ND, Telang F, Jayne M, Ma Y, Pradhan K, Zhu W, Wong CT, Thanos PK, Geliebter A, et al. Evidence of gender differences in the ability to inhibit brain activation elicited by food stimulation. PNAS 2009106 1249-1254. (https://doi.org/10.1073/ pnas.0807423106)

64 Guzzardi MA, Garelli S, Agostini A, Filidei E, Fanelli F, Giorgetti A, Mezzullo M, Fucci S, Mazza R, Vicennati V, et al. Food addiction distinguishes an overweight phenotype that can be reversed by low calorie diet. European Eating Disorders Review 201826 657-670. (https://doi.org/10.1002/erv.2652)

65 Volkow ND, Wang GJ, Telang F, Fowler JS, Goldstein RZ, Alia-Klein N, Logan J, Wong C, Thanos PK, Ma Y, et al. Inverse association between BMI and prefrontal metabolic activity in healthy adults. Obesity 2009 17 60-65. (https://doi.org/10.1038/oby.2008.469)

66 Thanos PK, Michaelides M, Gispert JD, Pascau J, SotoMontenegro ML, Desco M, Wang R, Wang GJ \& Volkow ND. Differences in response to food stimuli in a rat model of obesity: in-vivo assessment of brain glucose metabolism. International Journal of Obesity 200832 1171-1179. (https://doi.org/10.1038/ijo.2008.50)

67 Davidson TL, Chan K, Jarrard LE, Kanoski SE, Clegg DJ \& Benoit SC. Contributions of the hippocampus and medial prefrontal cortex to energy and body weight regulation. Hippocampus 200919 235-252. (https://doi.org/10.1002/hipo.20499)

68 Davidson TL, Kanoski SE, Chan K, Clegg DJ, Benoit SC \& Jarrard LE. Hippocampal lesions impair retention of discriminative responding based on energy state cues. Behavioral Neuroscience 2010124 97-105 (https://doi.org/10.1037/a0018402)

69 Sanguinetti E, Guzzardi MA, Panetta D, Tripodi M, De Sena V, Quaglierini M, Burchielli S, Salvadori PA \& Iozzo P. Combined effect of fatty diet and cognitive decline on brain metabolism, food intake, body weight, and counteraction by intranasal insulin therapy in 3xTg mice. Frontiers in Cellular Neuroscience 201913 188. (https://doi. org/10.3389/fncel.2019.00188)

70 Sanguinetti E, Liistro T, Mainardi M, Pardini S, Salvadori PA, Vannucci A, Burchielli S \& Iozzo P. Maternal high-fat feeding leads to alterations of brain glucose metabolism in the offspring: positron emission tomography study in a porcine model. Diabetologia 201659 813-821. (https://doi.org/10.1007/s00125-015-3848-5)

71 Bouter C, Henniges P, Franke TN, Irwin C, Sahlmann CO, Sichler ME, Beindorff N, Bayer TA \& Bouter Y. (18)F-FDG-PET detects drastic changes in brain metabolism in the Tg4-42 model of Alzheimer's disease. Frontiers in Aging Neuroscience 201810 425. (https://doi. org/10.3389/fnagi.2018.00425)

72 de Haan W, Mott K, van Straaten EC, Scheltens P \& Stam CJ. Activity dependent degeneration explains hub vulnerability in Alzheimer's disease. PLoS Computational Biology 20128 e1002582. (https://doi. org/10.1371/journal.pcbi.1002582)

73 Krabbe KS, Nielsen AR, Krogh-Madsen R, Plomgaard P, Rasmussen P, Erikstrup C, Fischer CP, Lindegaard B, Petersen AM, Taudorf S, et al. Brain-derived neurotrophic factor (BDNF) and type 2 diabetes. Diabetologia 200750 431-438. (https://doi.org/10.1007/s00125-0060537-4)

74 Erickson KI, Voss MW, Prakash RS, Basak C, Szabo A, Chaddock L, Kim JS, Heo S, Alves H, White SM, et al. Exercise training increases size of hippocampus and improves memory. PNAS 2011108 3017-3022. (https://doi.org/10.1073/pnas.1015950108)

75 Li B, Lang N \& Cheng ZF. Serum levels of brain-derived neurotrophic factor are associated with diabetes risk, complications, and obesity: a cohort study from Chinese patients with Type 2 diabetes. Molecular Neurobiology 201653 5492-5499. (https://doi.org/10.1007/s12035015-9461-2)

76 Zhen YF, Zhang J, Liu XY, Fang H, Tian LB, Zhou DH, Kosten TR \& Zhang XY. Low BDNF is associated with cognitive deficits in patients with type 2 diabetes. Psychopharmacology 2013227 93-100. (https:// doi.org/10.1007/s00213-012-2942-3)

77 Bariohay B, Lebrun B, Mo E \& Jean A. Brain-derived neurotrophic factor plays a role as an anorexigenic factor in the dorsal vagal complex. Endocrinology 2005146 5612-5620. (https://doi. org/10.1210/en.2005-0419)

78 Wang C, Bomberg E, Billington C, Levine A \& Kotz CM. Brainderived neurotrophic factor in the hypothalamic paraventricular nucleus reduces energy intake. American Journal of Physiology: Regulatory, Integrative and Comparative Physiology 2007293 R1003-R1012. (https://doi.org/10.1152/ajpregu.00011.2007)

79 Tonra JR, Ono M, Liu X, Garcia K, Jackson C, Yancopoulos GD, Wiegand SJ \& Wong V. Brain-derived neurotrophic factor improves blood glucose control and alleviates fasting hyperglycemia in C57BLKS-Lepr(db)/lepr(db) mice. Diabetes 199948 588-594. (https:// doi.org/10.2337/diabetes.48.3.588)

80 Ono M, Itakura Y, Nonomura T, Nakagawa T, Nakayama C, Taiji M \& Noguchi H. Intermittent administration of brain-derived neurotrophic factor ameliorates glucose metabolism in obese diabetic mice. Metabolism: Clinical and Experimental 200049 129-133. (https://doi.org/10.1016/s0026-0495(00)90988-0)

81 Cirulli F, Berry A, Chiarotti F \& Alleva E. Intrahippocampal administration of BDNF in adult rats affects short-term behavioral plasticity in the Morris water maze and performance in the elevated plus-maze. Hippocampus 200414 802-807. (https://doi.org/10.1002/ hipo.10220)

82 Obici S, Zhang BB, Karkanias G \& Rossetti L. Hypothalamic insulin signaling is required for inhibition of glucose production. Nature Medicine 20028 1376-1382. (https://doi.org/10.1038/nm1202-798)

83 Blazquez E, Velazquez E, Hurtado-Carneiro V \& Ruiz-Albusac JM. Insulin in the brain: its pathophysiological implications for states related with central insulin resistance, type 2 diabetes and Alzheimer's disease. Frontiers in Endocrinology 20145 161. (https:// doi.org/10.3389/fendo.2014.00161)

84 Ghasemi R, Haeri A, Dargahi L, Mohamed Z \& Ahmadiani A. Insulin in the brain: sources, localization and functions. Molecular Neurobiology 201347 145-171. (https://doi.org/10.1007/s12035-012-8339-9)

85 Jauch-Chara K, Friedrich A, Rezmer M, Melchert UH, G ScholandEngler H, Hallschmid M \& Oltmanns KM. Intranasal insulin suppresses food intake via enhancement of brain energy levels in humans. Diabetes 201261 2261-2268. (https://doi.org/10.2337/db12-0025)

86 Koch L, Wunderlich FT, Seibler J, Konner AC, Hampel B, Irlenbusch S, Brabant G, Kahn CR, Schwenk F \& Bruning JC. Central insulin action regulates peripheral glucose and fat metabolism in mice. Journal of Clinical Investigation 2008118 2132-2147. (https:// doi.org/10.1172/JCI31073)

87 Tarussio D, Metref S, Seyer P, Mounien L, Vallois D, Magnan C, Foretz M \& Thorens B. Nervous glucose sensing regulates postnatal

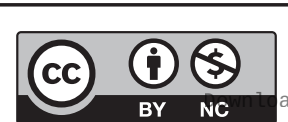

This work is licensed under a Creative Commons Attribution-NonCommercial 4.0 International License. ated from Bioscientifica com at 04/26/2023 12:37:54PM 
beta cell proliferation and glucose homeostasis. Journal of Clinical Investigation 2014124 413-424. (https://doi.org/10.1172/JCI69154)

88 Chen M, Woods SC \& Porte D, Jr. Effect of cerebral intraventricular insulin on pancreatic insulin secretion in the dog. Diabetes 197524 910-914. (https://doi.org/10.2337/diab.24.10.910)

89 Kullmann S, Fritsche A, Wagner R, Schwab S, Haring HU, Preissl H $\&$ Heni M. Hypothalamic insulin responsiveness is associated with pancreatic insulin secretion in humans. Physiology and Behavior 2017 176 134-138. (https://doi.org/10.1016/j.physbeh.2017.03.036)

90 Arnold SE, Arvanitakis Z, Macauley-Rambach SL, Koenig AM, Wang HY, Ahima RS, Craft S, Gandy S, Buettner C, Stoeckel LE, et al. Brain insulin resistance in type 2 diabetes and Alzheimer disease: concepts and conundrums. Nature Reviews: Neurology $2018 \mathbf{1 4}$ 168-181. (https://doi.org/10.1038/nrneurol.2017.185)

91 Posey KA, Clegg DJ, Printz RL, Byun J, Morton GJ, VivekanandanGiri A, Pennathur S, Baskin DG, Heinecke JW, Woods SC, et al. Hypothalamic proinflammatory lipid accumulation, inflammation, and insulin resistance in rats fed a high-fat diet. American Journal of Physiology: Endocrinology and Metabolism 2009296 E1003-E1012. (https://doi.org/10.1152/ajpendo.90377.2008)

92 Sanguinetti E, Guzzardi MA, Tripodi M, Panetta D, Selma-Royo M, Zega A, Telleschi M, Collado MC \& Iozzo P. Microbiota signatures relating to reduced memory and exploratory behaviour in the offspring of overweight mothers in a murine model. Scientific Reports 20199 12609. (https://doi.org/10.1038/s41598-019-48090-8)

93 Craft S, Baker LD, Montine TJ, Minoshima S, Watson GS, Claxton A, Arbuckle M, Callaghan M, Tsai E, Plymate SR, et al. Intranasal insulin therapy for Alzheimer disease and amnestic mild cognitive impairment: a pilot clinical trial. Archives of Neurology 201269 29-38. (https://doi.org/10.1001/archneurol.2011.233)

94 Kullmann S, Heni M, Veit R, Scheffler K, Machann J, Haring HU, Fritsche A \& Preissl H. Intranasal insulin enhances brain functional connectivity mediating the relationship between adiposity and subjective feeling of hunger. Scientific Reports 20177 1627. (https:// doi.org/10.1038/s41598-017-01907-w)

95 Heni M, Wagner R, Kullmann S, Veit R, Mat Husin H, Linder K, Benkendorff C, Peter A, Stefan N, Haring HU, et al. Central insulin administration improves whole-body insulin sensitivity via hypothalamus and parasympathetic outputs in men. Diabetes 2014 63 4083-4088. (https://doi.org/10.2337/db14-0477)

96 Leblhuber F, Steiner K, Schuetz B, Fuchs D \& Gostner JM. Probiotic supplementation in patients with Alzheimer's dementia - an explorative intervention study. Current Alzheimer Research 201815 1106-1113. (https://doi.org/10.2174/1389200219666180813144834)

97 Akbari E, Asemi Z, Daneshvar Kakhaki R, Bahmani F, Kouchaki E, Tamtaji OR, Hamidi GA \& Salami M. Effect of probiotic supplementation on cognitive function and metabolic status in Alzheimer's disease: a randomized, double-blind and controlled trial. Frontiers in Aging Neuroscience 20168 256. (https://doi.org/10.3389/ fnagi.2016.00256)

98 Elazab N, Mendy A, Gasana J, Vieira ER, Quizon A \& Forno E. Probiotic administration in early life, atopy, and asthma: a metaanalysis of clinical trials. Pediatrics 2013132 e666-e676. (https://doi. org/10.1542/peds.2013-0246)

99 Franceschi F, Ojetti V, Candelli M, Covino M, Cardone S, Potenza A, Simeoni B, Gabrielli M, Sabia L, Gasbarrini G, et al. Microbes and Alzheimer' disease: lessons from H. pylori and GUT microbiota. European Review for Medical and Pharmacological Sciences 201923 426-430. (https://doi.org/10.26355/eurrev_201901_16791)

100 Tremaroli V \& Backhed F. Functional interactions between the gut microbiota and host metabolism. Nature 2012489 242-249. (https:// doi.org/10.1038/nature11552)
101 Ley RE, Turnbaugh PJ, Klein S \& Gordon JI. Microbial ecology: human gut microbes associated with obesity. Nature $2006 \mathbf{4 4 4}$ 1022-1023. (https://doi.org/10.1038/4441022a)

102 Turnbaugh PJ, Hamady M, Yatsunenko T, Cantarel BL, Duncan A, Ley RE, Sogin ML, Jones WJ, Roe BA, Affourtit JP, et al. A core gut microbiome in obese and lean twins. Nature $2009 \mathbf{4 5 7} 480-484$. (https://doi.org/10.1038/nature07540)

103 Castaner O, Goday A, Park YM, Lee SH, Magkos F, Shiow STE \& Schroder H. The gut microbiome profile in obesity: a systematic review. International Journal of Endocrinology 201820184095789. (https://doi.org/10.1155/2018/4095789)

104 Vogt NM, Kerby RL, Dill-McFarland KA, Harding SJ, Merluzzi AP, Johnson SC, Carlsson CM, Asthana S, Zetterberg H, Blennow K, et al. Gut microbiome alterations in Alzheimer's disease. Scientific Reports 20177 13537. (https://doi.org/10.1038/s41598-01713601-y)

105 Jiang C, Li G, Huang P, Liu Z \& Zhao B. The gut microbiota and Alzheimer's disease. Journal of Alzheimer's Disease 201758 1-15. (https://doi.org/10.3233/JAD-161141)

106 Sanguinetti E, Collado MC, Marrachelli VG, Monleon D, SelmaRoyo M, Pardo-Tendero MM, Burchielli S \& Iozzo P. Microbiomemetabolome signatures in mice genetically prone to develop dementia, fed a normal or fatty diet. Scientific Reports $2018 \mathbf{8} 4907$. (https://doi.org/10.1038/s41598-018-23261-1)

107 Alosco ML, Spitznagel MB, Strain G, Devlin M, Cohen R, Paul R, Crosby RD, Mitchell JE \& Gunstad J. Improved memory function two years after bariatric surgery. Obesity 201422 32-38. (https://doi. org/10.1002/oby.20494)

108 Tremaroli V, Karlsson F, Werling M, Stahlman M, KovatchevaDatchary P, Olbers T, Fandriks L, le Roux CW, Nielsen J \& Backhed F. Roux-en-Y gastric bypass and vertical banded gastroplasty induce long-term changes on the human gut microbiome contributing to fat mass regulation. Cell Metabolism 201522 228-238. (https://doi. org/10.1016/j.cmet.2015.07.009)

109 DeFronzo RA, Tobin JD \& Andres R. Glucose clamp technique: a method for quantifying insulin secretion and resistance. American Journal of Physiology 1979237 E214-E223. (https://doi.org/10.1152/ ajpendo.1979.237.3.E214)

110 Berti V, Vanzi E, Polito C \& Pupi A. Back to the Future: the absolute quantification of cerebral metabolic rate of glucose. Clinical and Translational Imaging 20131 289-296. (https://doi.org/10.1007/ s40336-013-0030-2)

111 Lammertsma AA. Forward to the past: the case for quantitative PET imaging. Journal of Nuclear Medicine 201758 1019-1024. (https://doi. org/10.2967/jnumed.116.188029)

112 Roiser JP, Linden DE, Gorno-Tempinin ML, Moran RJ, Dickerson BC \& Grafton ST. Minimum statistical standards for submissions to Neuroimage: clinical. NeuroImage. Clinical 201612 1045-1047. (https://doi.org/10.1016/j.nicl.2016.08.002)

113 Eklund A, Nichols TE \& Knutsson H. Cluster failure: why fMRI inferences for spatial extent have inflated false-positive rates. PNAS 2016113 7900-7905. (https://doi.org/10.1073/pnas.1602413113)

114 Muller VI, Cieslik EC, Laird AR, Fox PT, Radua J, Mataix-Cols D, Tench CR, Yarkoni T, Nichols TE, Turkeltaub PE, et al. Ten simple rules for neuroimaging meta-analysis. Neuroscience and Biobehavioral Reviews 201884 151-161. (https://doi.org/10.1016/j. neubiorev.2017.11.012)

115 Nepal B, Brown L \& Ranmuthugala G. Modelling the impact of modifying lifestyle risk factors on dementia prevalence in Australian population aged 45 years and over, 2006-2051. Australasian Journal on Ageing 201029 111-116. (https://doi.org/10.1111/j.17416612.2010.00392.x)

Received in final form 27 September 2019

Accepted 7 October 2019

Accepted Preprint published online 7 October 2019 https://ec.bioscientifica.com https://doi.org/10.1530/EC-19-0348 (c) 2019 The authors Published by Bioscientifica Ltd

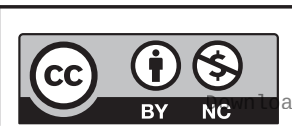

This work is licensed under a Creative Commons Attribution-NonCommercial 4.0 International License. ded from Bioscientifica com at 04/26/2023 12:37:54PM 